\title{
Jyndevad Forsøgsstation - en opvækst ved grænsen
}

Af THORBJørn HeICK

Forfatterens forældre, Frederik og Ingeborg Heick, var forstanderpar på Jyndevad Forsogsstation fra 1939 til 1959. Frederik Heick var samtidig folketingspolitiker fra 1945 til 1959. Formålet med oprettelsen af forsegsstationen i Jyndevad var at gavne landbruget på sandjorden. Thorbjørn Heick, født 1936, er pensioneret præst. Efter opvæksten på Jyndevad Forsegsstation blev han student fra Tønder Statsskole i 1955. Efter elevophold på Askov Højskole og teologistudium i København var han lærer på Rønshoved Højskole inden præstegerningen i Grindsted-Nollund-Urup og de sidste 27 år i Tønder, hvor forfatteren nu nyder sit otium.

I 2009 er det 70 år siden, at Jyndevad Forsøgsstation blev bygget, og hvor mine forældre, Frederik og Ingeborg Heick, var forstanderpar frem til 1959. Vi var seks børn, der voksede op der. Som den ældste, født i november 1936, har jeg fået det hele med på den måde, at jeg kan huske denne epoke fra begyndelsen, og den har jeg nu genoplevet ved at nedskrive de følgende erindringer.

Min far kom til Sonderjylland for at tjene. Han ville være landbrugskandidat, men langt op i tiden var det sådan, at for at komme ind på Landbohøjskolen skulle man først have arbejdet fire år i landbruget. Min far tjente bl.a. som fodermester på Rodding-kanten. Merret, den lille datter på gården, og min far blev gode venner, og det venskab fortsatte i Sønderjylland familierne imellem, da Merret og Gudmund Fink drev landbrug i Stoltelund syd for Tinglev. Det er fra dem, vi har julesangen "Nissen er en kunstig mand «.

Landbrugsskole skulle min far også på. Det blev til en god tid på Ladelund. Højskole var der ikke råd til, men Askov lå i nærheden. Og der var også en forsøgsstation, som fik stor betydning, fordi min far blev assistent der, da han var blevet landbrugskandidat. Men først skulle han som så mange andre bondestudenter sulte sig igennem studierne i København. Han vejede kun 45 kilo, da han var færdig. Han lignede det, vi senere kaldte en koncentrationslejrfange, så meget, at da min yngste søster Dorete (født 1952) som barn så et 
billede af ham fra dengang, så spurgte hun sin mor: Hvordan kunne du dog gifte dig med ham?

Min far blev assistent på Askov Forsøgsstation. Det skal nævnes, fordi det var ånden derfra, der blev bragt til Jyndevad og dermed til grænselandet. Når jeg som ung kom på besøg på Askov Forsøgsstation (bl.a. mens jeg var elev på Askov Højskole 1955-56), så kunne jeg ikke andet end kalde forstanderparret, Karsten og Elisabeth Iversen, mine åndelige bedsteforældre. Her var der en grundtvigsk livsglæde, udstrålet af disse to prægtige mennesker, en ånd som man senere mødte på Jyndevad. Meget lærte min far på Askov. Også at spille tennis - på Jyndevad havde vi gennem alle årene en tennisbane. $\mathrm{Og}$ jeg tror også, at det var derfra, mine forældre havde deres interesse for at spille bridge. Det blev på bedste grundtvigske vis også spillet til slut juleaften og desuden livet igennem ved alle tænkelige lejligheder.

Den 1. november 1933 begyndte min far som landbrugskonsulent og købte hus i Toftlund. Det var vanskelige år også i landbruget. Mange måtte gå fra gården. Min far har fortalt, at engang han havde ærinde til en gård, var der ingen hjemme. Det undrede ham, og han blev stående lidt. Men så dukkede konen op: "Gud ske lov, at det kun var dig. Vi troede, det var advokaten. Og så gemte vi os.«

I Toftlund mødte min far så hende, der blev min og mine fem søskendes mor, Ingeborg Detlefsen, født juli 1916. Det var her, telefonstationen kom til at spille en rolle, for en sådan bestyrede min mormor ved hjælp af sine seks døtre. De to sønner blev elektrikere som deres far, min morfar, Christen Detlefsen. Alle »telefonpigerne« besad en formidabel evne til at »slå over « fra sønderjysk til rigsdansk, som de talte helt uden accent. Noget, jeg og mine søskende, der kom til at vokse op i Sydvestsønderjylland, aldrig lærte.

Da min far kom til Toftlund ville han gerne have nogen at spille tennis med. Og hvad gør man så? I forvejen havde han fået centralen til at fungere som sin telefonsvarer. Så han ringede til telefoncentralen og spurgte, om de kendte nogen. Og svaret var næsten bukke-bruse i omvendt form. De to søstre, der havde vagt, svarede: »Ja, vi har da en lillesøster, Ingeborg, som vist gerne vil have nogen at spille med.« Og sådan blev det. Så de spillede hver morgen fra klokken seks til syv. $\mathrm{Og}$ trods aldersforskellen på elleve år blev de $\mathrm{i}$ den grad gode venner, at de blev forlovet på min fars 30 års fødselsdag den 12. december 1934. Fra Askov var de undervejs til Toftlund med 30 peberbøsser. Men de havde hørt en fugl synge, så de havde aftalt med 


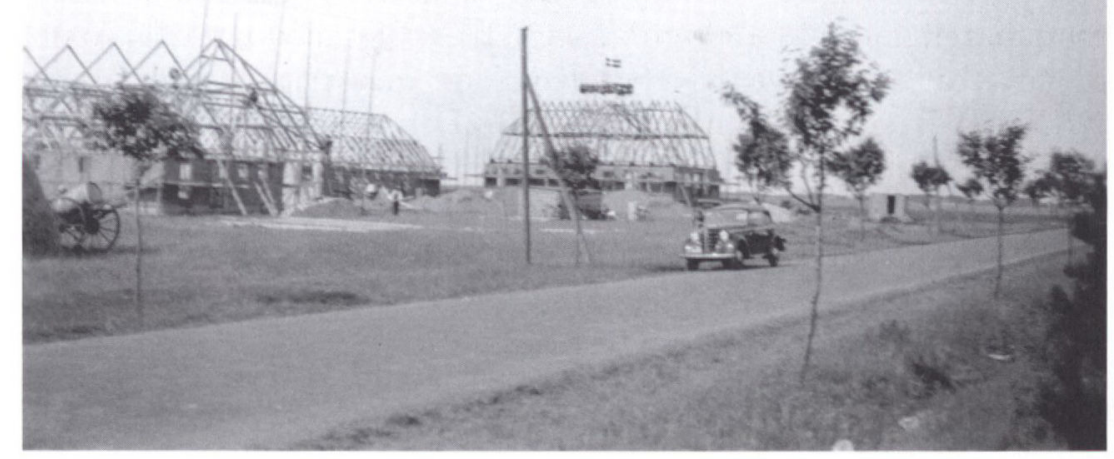

Rejsegilde på Jyndevad Forsegsstation. 1939. Privat foto.

brugsuddeleren, at peberbøsserne kunne leveres tilbage. Året efter, 12. december 1935, blev de gift. Og i november 1936 blev jeg født, i juni 1938 min søster Lisbet.

Da vores mor blev gift, var hun 19 år gammel. I 1939, da hun begyndte som husmor på forsøgsstationen, var hun altså blot 23 år gammel. De første år var kokkepigen ofte både ældre og mere erfaren end hende. Hendes ophold på Johanne Hansens Als Husholdningsskole kom kun til at vare fra februar til april 1935. Derefter var hun fra maj til november 1935 sammen med en søster i huset på Lindet Skovridergård. Det var hendes forberedelse til tiden som husmor. Johanne Hansens vinterkursus var begyndt 1 . november, og da vores mor blev forlovet den 12. december, blev det kun de sidste to måneder, hun fik der. Højskolepræget kom nok til at betyde mest for hende, både kulturelt som romantiker og nationalt som optaget af det, som begyndte med Det unge Grænseværn og de store stævner på Dybbøl og i Tønder i 1933.

Genforeningen må have kostet den danske stat en del penge. Der skulle afvandes, plantes og dyrkes. En forsøgsstation på sandjorden skulle hjælpe til med at finde ud af, hvordan det bedst kunne gøres der, og vise det for landbrugerne, både i mark og have. Jeg/vi var 
dengang ret stolte over det danske system, hvor forskning og praksis var så nært forbundet. Ikke som f.eks. i Tyskland, hvor landbrugsforsøg var noget meget teoretisk, meget videnskabeligt.

Ud over landbruget var der også efter Genforeningen meget at gøre med infrastrukturen. Samtidig med forsøgsstationen blev der bygget en transformatorstation med billig elektrisk strøm fra værket i Aabenraa. Og vi havde statstelefon i Sønderjylland. Forsøgsstationens telefonnummer var 4316. Det er det stadigvæk. Blot med fire cifre foran. Men også dengang var vi i Sønderjylland med på noderne. I dette tilfælde med en telefon med drejeskive. Den stod på bordet. Ikke et mærkeligt apparat, der hang på væggen med et drejehjul, som man kaldte centralen op med, som det var hos Jysk Telefon "oppe i det gamle land «, som det hed (medmindre man var gammel sønderjyde, for så sagde man "nede i Jylland «). Og hvis man skulle spare, og det skulle eller ville mange, så havde man partstelefon. $\mathrm{Og}$ så skulle man, inden man drejede på håndtaget, sige »Hallo« for at sikre sig, at der ikke var andre på.

Toenhalv km syd for Store Jyndevad ligger Lille Jyndevad. Den ligger ved en vej tæt på grænsen. Vejen går fra Sæd via Lydersholm, Rens, Lille Jyndevad, Sofiedal og Frøslev til Padborg. Fra Rens er der fire kilometer til Store Jyndevad. Fra Jyndevad Forsøgsstation er der halvanden kilometer til den landsby, som blev vores landsby. Topografien i Store Jyndevad var mere enkel end den i Rens. Den udgjordes her af to veje, der krydsede hinanden, en øst-vest-vej, dengang del af hovedvej otte, blev krydset af en nord-syd vej. »Æ hjørn « var byens centrum, også for byens drenge. Her lå vandrerhjemmet, hvor jeg oplevede den myndige Carla Schibler, den legendariske Tage Albertsen, og den af os alle elskede Solvejg Refslund. Det var en tidligere kro, hvis staldlænge nu var ombygget til at huse både købmand Andresen og bager Lorenzen.

Købmand Andresen havde altid en cigaret i munden, også når han og fruen spillede bridge med mine forældre. Bager Lorenzen havde en hestetrukken brødvogn. Han troede nok, at jeg var lige så praktisk som de andre drenge, så han lod mig passe hest og vogn, mens han var inde hos os. Men jeg mindes engang, hvor jeg ville trække den græssende hest udad, men trak den mod grøften. Kassevognen væltede over mig, og jeg havde ingen luft til at råbe om hjælp. Men heldigvis var det efter løvfald, så fodermester Aksel Mumm så mig.

Efter bageren kom smed Marshalls hus. Her fik vi hestene skoet. 
Der havde været en smed Buch øst for kroen. Der var to skomagere, en af dem hed Jørgen Vind. Han var også en af de fem til seks daglejere på forsøgsstationen.

Man skal ikke langt væk fra hovedvejen på sandjorden, før man mod nord kom til idyllen ved mølledammen. Her lå først Chr. Nissens gård. Så kom mejeriet med sin specielle lugt, når man kom efter et pund smør. Så kom slusen og derefter møllen, der endnu i min barndom lavede jævnstrøm til byen. Samuel Münchow (senere dansk landdagsmand i Kiel) arbejdede der omkring århundredskiftet. En aften kom mølleren hjem og var sur, fordi han ikke var budt med til et gilde, der netop var i gang. "Sluk for strømmen«, sagde han. Og så var Jyndevad uden lys $\mathrm{i}$ en halv time.

Forsøgsstationens marker strakte sig fra hovedvej otte mod syd, næsten helt ned til Lille Jyndevad. Mod syd kunne vi kun se til grænsen. Selvom vi kunne se over den, så var det hertil, vor verden gik. Grænsen var lukket under hele 2. Verdenskrig, og efter krigen var den også lukket, så længe englænderne var der. Før 1920 var der ingen grænse der. Og det var mærkeligt for os, der var født efter 1920, at høre folk, der havde oplevet det og stadig ofte levede $i$, at der var ingen grænse, når de fortalte. Men ellers havde de fleste af os nord for den grænse nok $i$ os selv, nok $i$ at leve vort liv, mens vi håbede på, at den grænse holdt. Og der vedblev at være forskel på hverdagen nord og syd for grænsen.

Hen i 1930'erne begyndte man i landbrugets organisationer og inden for forsøgsvæsenet under Statens Planteavlsudvalg at tale om betimeligheden af at oprette en forsøgsstation for de sandjorder, der prægede midtlandet, gesten. Det førte til, at skovrider Fromsejer blev sat til at annoncere om køb af jord til juletræer. Dels ville man vel gå stille til værks, dels ville man have noget rigtigt dårligt jord, det rene sand. Og det bedst egnede var det tilbud, man fik fra gårdejer Andreas Nielsen, Midtholm, en kilometer vest for Jyndevad. En handel blev aftalt. Arkitekt Petersen i Tønder skulle lave tegninger til byggeriet. Han havde i samme stil tegnet gården Tøndermark, som Henrik Petersen, Korntved, havde ladet bygge lige øst for Tønder lige inden for bygrænsen, så han kunne levere børnemælk til købstaden.

Jyndevad Forsøgsstation blev bygget $\mathrm{i} 1939$. Og et af næsten utallige argumenter for vil jeg straks nævne. Det kom fra en gammel gårdejer fra Store Jyndevad, Christian Nissen, som også havde haft, hvad vi nu kalder en maskinstation, bl.a. et tærskeværk som bl.a. kom til 
forsøgsstationen. Efter at jeg i 1974 var kommet tilbage til egnen og var sognepræst $\mathrm{i}$ Tønder, mødte jeg på mine rundture for at hilse på de indlagte på sygehuset også engang Christian Nissen. Han var da ret svag. Men da vi havde snakket lidt, og han fandt ud af, hvem jeg var, eller vel mere hvor jeg kom fra, så formelig rettede han sig op og sagde: $» Æ$ forsøgsgård er det bedste, der er sket i Jyndevads historie.« Han talte på generationers vegne. Der var også argumenter imod forsøgsstationen. Jeg kender tre, som vil jeg nævne.

\section{Tre argumenter mod forsøgsstationen}

Landbrugsministeriet godkendte planerne. Men så kom det første argument imod. $\mathrm{Og}$ det kom fra Udenrigsministeriet! Man frarådede at bygge så nær på grænsen, for af alle Versailles-grænser var denne grænse den eneste, som Hitler endnu ikke havde gjort noget ved. Måske ville Hitler nøjes med en symbolsk ændring heroppe. Og derfor tilrådede Udenrigsministeriet, at man byggede den forsøgsstation lidt længere nordpå. Planteavlsudvalget fik Landbrugsministeriet til at svare, at hvis grænsen blev flyttet, så ville en forsøgsstation fra eller til ikke gøre noget. »Vi bygger i Jyndevad, og der bliver vi!«

Så kom det næste argument imod. Da skødet endelig skulle underskrives, vægrede Andreas Nielsen sig. Han havde jo solgt jorden som juletræsjord, og nu var det staten, der købte jorden til noget helt andet. Og så måtte han have en helt anden pris for jorden! Det blev noget pinligt, for planerne var jo langt fremme, og Andreas Nielsen kunne vel have sagt fra før. $\mathrm{Og}$ så viste det sig igen, at "milde kvinder, hvor har de magt! «. Hans kone bankede blidt i bordet - hun havde vist også skudt penge i Midtholm i sin tid - og Andreas Nielsen skrev under. Han blev noget senere og resten af sit liv en trind og hyggelig havemand på forsøgsstationen, hvis køkkenhave gerne skulle yde så meget som muligt til den store husholdning.

Der var fra begyndelsen ti karle på kost, hvis man hertil regner to agronomer, som de kaldes nu om dage. Den ene af disse to assistenter var en af min fars gamle venner, en ungkarl der hed Ladegaard. Han passede regnskab og laboratorium. Desuden var der en markassistent, der ledede karlene: en fodermester, en forkarl, en andenkarl og fire til fem elever. I stuehuset boede der tre piger: kokkepige, stuepige og barnepige. Og dertil kom efterhånden seks børn. Så det var et stort bord i spisestuen. Og der var liv og glade dage de tyve år igennem. 


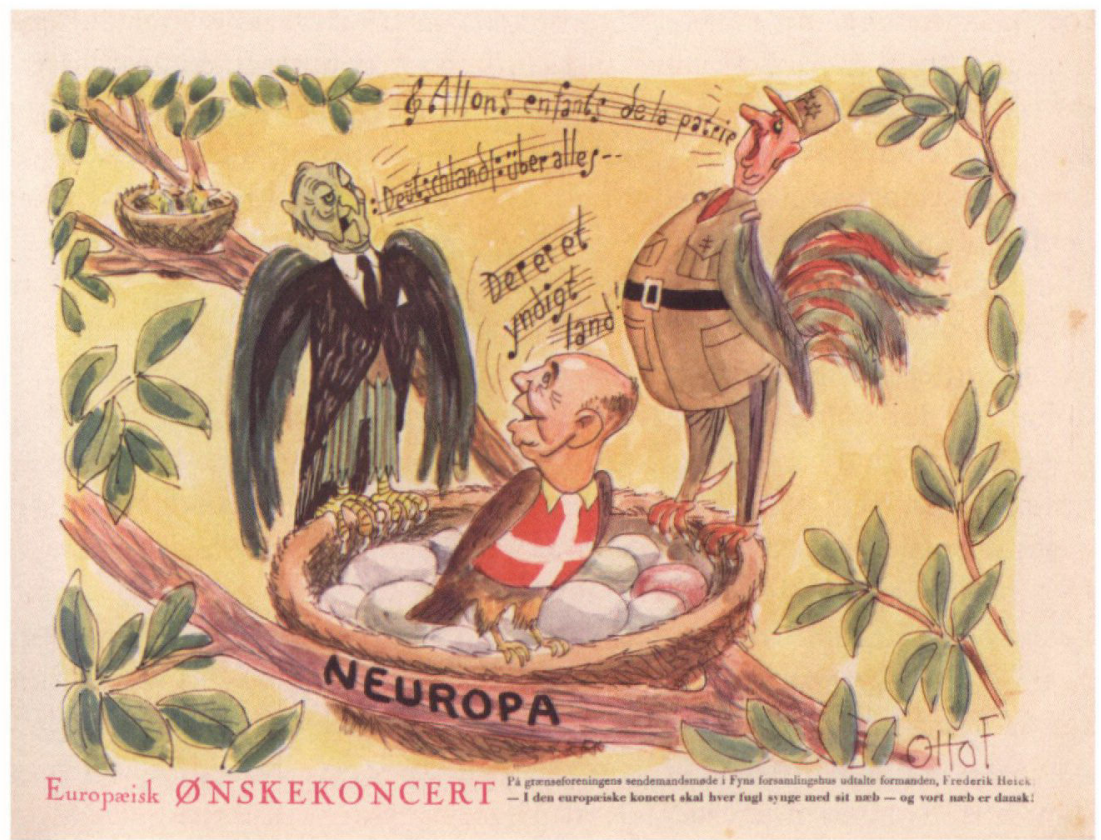

Forfatterens far, Frederik Heick (1904-1971), var både stærkt engageret $i$ det nationale og en overbevist tilhænger af europæisk integration. I "æ Rummelpot « fra 1962 afbilledes han som forsvarer for det danske sprog $i$ Europa. Frederik Heick var formand for Grænseforeningen 1961-1966 og derefter næstformand indtil sin død. Foto: Museum Sonderjylland - ISL-Lokalhistorie.

Ikke blot på forsøgsstationen, men på hele egnen bidrog disse unge mennesker til liv i grænselandet. Der var skiftedag 1. maj og 1. november. Nogle var der et halvt år, nogle et helt år, enkelte længere. Det blev til mange unge mennesker, der i disse omgivelser fik et af deres livs højdepunkter.

Så der var mange her, der på den måde kunne se det gode ved den forsøgsstation. Desuden kom der gennem årene næsten utallige besøgende, både danske og tyske landbrugsforeninger, husmandsforeninger, husmoderforeninger osv. Forstanderparret, mine forældre, blev et afholdt par. De havde også en god presse i de adskillige aviser, landsdelen havde dengang. "æ Rummelpot« havde næsten hvert år min far som kært offer. Det varede ved, også da han havde forladt Sønderjylland og Folketinget og i 1959 var blevet direktør for Hedeselskabet, i hvis bestyrelse han havde siddet i mange år. I 1960'erne 
var han formand for Grænseforeningen, og fra den tid er der en tegning af Otto F. med Adenauer, de Gaulle og min far som fugle siddende på kanten af den samme rede med indskriften "Neuropa ". Hver synger sin nationalsang. Billedteksten lyder: "Europæisk ønskekoncert: På Grænseforeningens sendemandsmøde i Fyns Forsamlingshus udtalte formanden, Frederik Heick: I den europæiske koncert skal hver fugl synge med sit næb - og vort næb er dansk!«

Det tredje argument mod at oprette forsøgsstationen kom uofficielt fra hjemmetysk side. Forsøgsstationen blev drevet delvist som almindeligt landbrug. Mange marker bestod af små parceller, hvor man forsøgte sig med forskellige sorter, forskellige slags og mængder gødning osv. De blev beset hver for sig, også af de mange besøgende. Og derefter høstet hver for sig, vejet, målt og undersøgt. Men jorden skulle jo pløjes osv. Dertil havde vi fem heste.

Vi havde en mindre eng i nærheden af gården, 500 meter nede ad vejen til den lille landsby Stade, ned til Sønderåen. Hertil red vi om sommeren vore fem heste ned hver dag efter arbejdstid. Det var et af dagens spændende momenter, når vi som lidt større børn fik lov at ride dem ned til engen, uden saddel naturligvis. Og det gik i hurtigste galop over hovedvejen og nedad grusvejen, for hver hest ville være den første på engen. Så græssede de der. Og på den måde blev engen ved med at være en pæn eng. For den var ikke stor nok til, at der blev høstet hø der. Men så fra sidst i 1940'erne kom den forste traktor, Ferguson'en, og senere flere og andre slags. Heste blev nu overflødige. Og engen blev ikke mere græsset af, så den blev et jammerligt syn.

Vi havde også tyve røde køer og en fyldt svinestald. Derfor en fodermester. Og derfor leverede vi mælk til mejeriet i Store Jyndevad. Det kostede selvfølgelig penge at drive den forsøgsstation, men i begyndelsen tjente landbruget selv det halve ind. Og samtidig var vi på øjenhøjde og i fællesskab med folk.

Mejeriet var privat, og det var især de store landbrug, der var tyske. I Lille Jyndevad hed den største bonde Jep Nissen. Han var en af de ledende i mindretallet og vel en af de mest nidkære. Så han skubbede både på sine egne og andres af det tyske mindretals sønner, så de meldte sig som frivillige til Hitlers krig. Jep Nissen brugte også mund, når mælkeleverandørerne holdt møde på kroen i Store Jyndevad. Engang udtalte han, at det var dog spild af statens penge, at den forsøgsstation var blevet bygget. Den bemærkning må være faldet efter, at Danmark var blevet besat den 9. april 1940. Min far sagde til Jep 
Nissens udtalelse om pengespild: „Vi skulle måske have købt et par luftværnskanoner i stedet for?«

\section{Startperioden fra 1939}

Forsøgsstationen kom til at ligge omtrent lige mellem Rens og Store Jyndevad. Når den kom til at hedde Jyndevad Forsøgsstation, skyldes det, at den jord, den blev bygget på, hørte til Jyndevad. Det var den jord, der tidligere hørte til gården Midtholm, en udflyttergård fra Jyndevad. Der var også en »Vesterholm « 500 meter vest for Midtholm, og både et »Østerholm « og et "Ny Østerholm « øst for Store Jyndevad. I 1939 flyttede mine forældre samt min søster Lisbet og jeg fra Toftlund. Vi boede først i Rens, en landsby fire kilometer vest for Store Jyndevad, som lå halvanden kilometer øst for det sted, hvor forsøgsstationen var ved at blive bygget. $\mathrm{Og}$ nu begynder jeg at kunne huske glimt af, hvad jeg har set.

I centrum af Rens lå bageren, Boysen hed han. Han var dansk, så vi handlede hos ham, selv om vi selvfølgelig også handlede hos den tyske bager Lorenzen i Store Jyndevad. Han bragte også brød ud med hestevogn. Bager Boysens hjørne var centrum, for der gik fem veje ud herfra. En mod vest forbi Rens molle og mod Lydersholm. Et stykke ude ad den gik en vej mod skovene i syd, hvor vi op til hver jul kørte ud og hentede juletræ hos de flinke skovfogedfolk, Rasmussens. Plantagen gik næsten helt ned til grænsen, så det var ad den rute, min far engang sidst under Besættelsen førte en deserteret tysk soldat, som far havde fået $i$ opdrag at hjælpe, tilbage over grænsen. Min far fortalte af og til om denne spadseretur i ly af mørket, hvor de to ikke fulgtes ad, men hvor soldaten skulle holde sig nogle meter bag ved far. En anden vej gik mod nord mod Burkal, på den boede slagter Langholz. Han var tysk, men var den eneste slagter. Desuden en tysk købmand og over for ham en kro, hvor der 1940'erne igennem kom kino en gang om måneden. Herfra husker jeg, at jeg sammen med min bror, Johannes (født juli 1940), engang efter 1945 så krigsfilmen »I Konvoj over Nordatlanten«. De tyske u-bådes torpedoer skar sig gennem vandet, sommetider gik den blot en meter fra det skib, vi fulgte i filmen, men sommetider ramte den. Min lillebror kunne ikke tåle at se på, at et skib blev ramt, så hver gang en torpedo blev fyret af, lod han sig falde ned mellem bænkene.

Den tredje vej fra bagerens centrum i Rens gik mod øst hen mod 


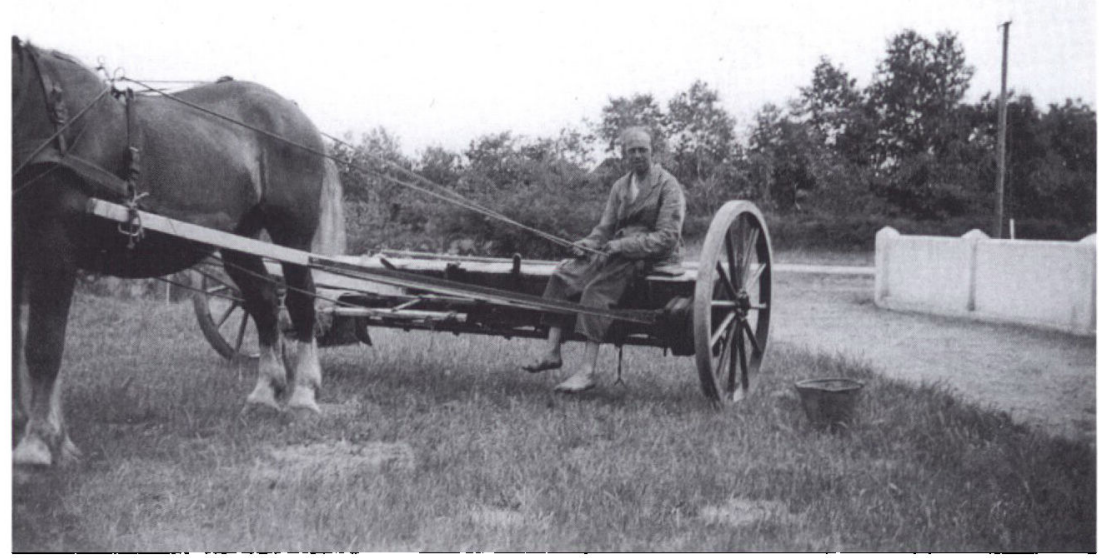

Frederik Heick kommer træt hjem fra Rens. 1939. Privat foto.

Jyndevad, først hen ad bygaden forbi endnu en dansk købmand og så ud på hovedvej otte. Den rute benyttede jeg i sommeren 1939 til på min lille trehjulede cykel at cykle de tre kilometer hen til byggeriet. Selve turen husker jeg ikke, men jeg husker, at jeg stod inde i det ufærdige stuehus og kiggede op i det hul, hvor senere trappen gik op til soveværelserne på første sal. Det er det første, jeg husker, toethalvt år gammel, eller måske det andet.

Den fjerde vej gik mod sydøst ned mod gendarmerigården. Gendarmerne med deres fine blå uniformer boede som regel med deres familier i enkelthuse i småbyerne eller blot langs vejene ved grænsen. Ligesom forsøgsstationens folk var disse gendarmfamilier for de få danske ved grænsen et kærkomment dansk tilskud. Når der var møder i forsamlingshuset, så var der dækket tre kaffeborde op, hver vel med 24 pladser. Gendarmfamilierne fyldte et, forsøgsstationens folk et, folk fra Store og Lille Jyndevad og omegn et.

Men i den mørkerøde gendarmerigård i Rens boede der flere familier, blandt andet vagtmester Kroghs, hvis søn, Arne, jeg fulgtes med på vej til og fra Statsskolen i Tønder og stationen i Bylderup-Bov. Den femte vej førte mod sydvest ned mod Pebersmark, hvor der var grænseovergang indtil 9. april 1940, og så igen fra henimod 1950. Men 
selv om grænsen var lukket i denne lange tid, så havde vi i min familie på forunderlig vis stadig forbindelse med familien Lindstrøm i Kirkevang i Ladelund, sydvest for Pebersmark. Lindstrøm var vandrelærer, glad og cigarrygende. Måske er det nogle af disse cigarer, der alligevel havde givet grænseovergang. Ad den vej lå i Rens nogle husmandsagtige huse, $i$ et af dem boede vor maler, og i det næste boede vi, mens forsøgsstationen blev bygget. Og det er på den vej, jeg husker mit første glimt i mit liv, nemlig min far komme kørende hjem med en hest foran en kunstgødningsspreder, som han sad på. Så det må have været foråret 1939 .

Lidt længere nede ad den vej lå en betydningsfuld dansk bastion, Rens Efterskole. Forstanderen, husker jeg, hed Godfred Hansen. Hans kone var fra Bergen og talte det smukkeste norsk. Hans forgænger hed Jensen og var den, der tidligst havde skubbet på for at få en forsøgsstation bygget. Godfred Hansen var kunstinteresseret, Willumsen var en af hans maler-helte. Jeg husker Godfred Hansen holde et hengivent foredrag om ham og hans billeder.

Rens Efterskole fungerede også som områdets danske forsamlingshus. I håndboldturneringer var de Jyndevads arvefjender. Men noget, som forsøgsstationens ugifte landbrugskandidater, assistenterne, syntes godt om, var efterskolens husholdningslærerinder. Det førte til flere gode ægteskaber. Vores postbud, Peter Post, efternavn Cornelsen, udgående fra Jyndevad posthus sammen med en anden post, som også hed Peter (Poulsen), fik sig også en husholdningslærerinde. Hun hed Annegrethe, og som Cornelsen blev hun leder af vandrerhjemmet i Store Jyndevad efter Solvejg Refslund, og desuden ledede hun gymnastik og folkedans, både lokalt og på amts- og regionsplan. I de første år var det Peter Posts far, der var kom med post til os. Jeg var fascineret af, at han stod på sin cykel via en pind, der stak ud fra baghjulets nav. Jeg fatter stadig ikke, hvordan han gjorde det. Min bedstefar i Hovborg gjorde det på samme måde.

\section{Dagliglivet på Jyndevad}

Forsøgsstationen, som ligger lige syd for hovedvej otte, var trelænget. Som et stort $\mathrm{E}$ (uden den mellemste streg) ligger den vendt med fløjene ud mod vejen med flagstangen midtfor. Stuehuset ligger mod vest. Hovedindgangen er ad en trappe ud mod gårdspladsen. Går man i forstuen til venstre, kommer man først til "lille kontor», hvor 
regnskabsassistenten sad. Næste rum var selve kontoret, hvor min far havde skrivebord, og hvor telefonen stod. Den tyske nabo kom over for at låne telefonen, men selv om han var en ivrig "tysker", så forbød naboskabet ham at reagere, hvis der lå illegale blade på skrivebordet. I kontoret var der en lænestol i de to hjørner, den ene ovre ved radioen. I det fjerde hjørne var en hjørnebænk og et bord med et par stole, beregnet til møder, men også, som de to lænestole, brugt af karlene om aftenen, så de kunne læse aviser og høre radio. I det næste rum mod sydvest var familiens private stue, hvor min far og mor sov til middag. Jeg begriber ikke, hvordan de kunne være på den lille sofa, men de var glade for hinanden. Fra denne stue var der en dobbeltfløjet dør ind til familiens private spisestue. I den døråbning stod taleren, når der var sammenkomst med foredrag, for eksempel grænselandskonventet. Selve spisestuen blev brugt ved højtidelige lejligheder, ved familiefester og jule- og nytårsaften, hvor de få vagthavende karle og piger var med. Nytårsaften selvfølgelig med grønlangkål, hvor min far sagde, at af sundhedsmæssige grunde hørte der en snaps til. Mange af pigerne fik ofte her deres livs første snaps.

Til daglig spiste familien og karlene i dagligspisestuen, som man også kunne komme ind til ad en lille trappe fra stuehusets nordside. Oven over denne trappe lå på første sal de to pigeværelser, kokkepigens og de to andres. Engang mens min søster Lisbet tjente som pige, fik pigerne den - meget dumme, syntes min far - idé at smide vand ned derfra på karlene. Det blev skarpt påtalt. Karlene skulle ikke generes der. De skulle i fred og ro kunne komme til og fra morgenmad kl. 6.30, middag kl. 12.00 og aftensmad kl. 18.00.

Især middagsmaden spiste karlene hurtigt, for der var middagspause til kl. 13.00. Så jo før færdig, des længere hvil. Mine evt. gode manerer ved bordet har jeg fra dette spisebord, for min mor brugte gerne sine børn at rette på, når det var en af karlene, hun ville lære en bedre maner. Omkring dette bord var der hver onsdag kl. 21.00 aftenkaffe (om sommeren frugtgrød) med ivrig sang af højskolesangbogen. Her var også pigerne med. Og det er ikke mindst herfra, at jeg kan numrene på ret mange af sangene i 14. udgave og ret mange af disse udenad. Og så var der selvfølgelig køkken med dertil hørende spisekammer, opvaskerum og anretterværelse. Det eneste, vi børn kunne blive sat til, var en gang imellem at hjælpe med opvasken.

Som nævnt var der en lille trappe op til stueplanet. Det skyldes, at der var kælder under det meste af huset, fyrrum, saltkar, viktualie- 


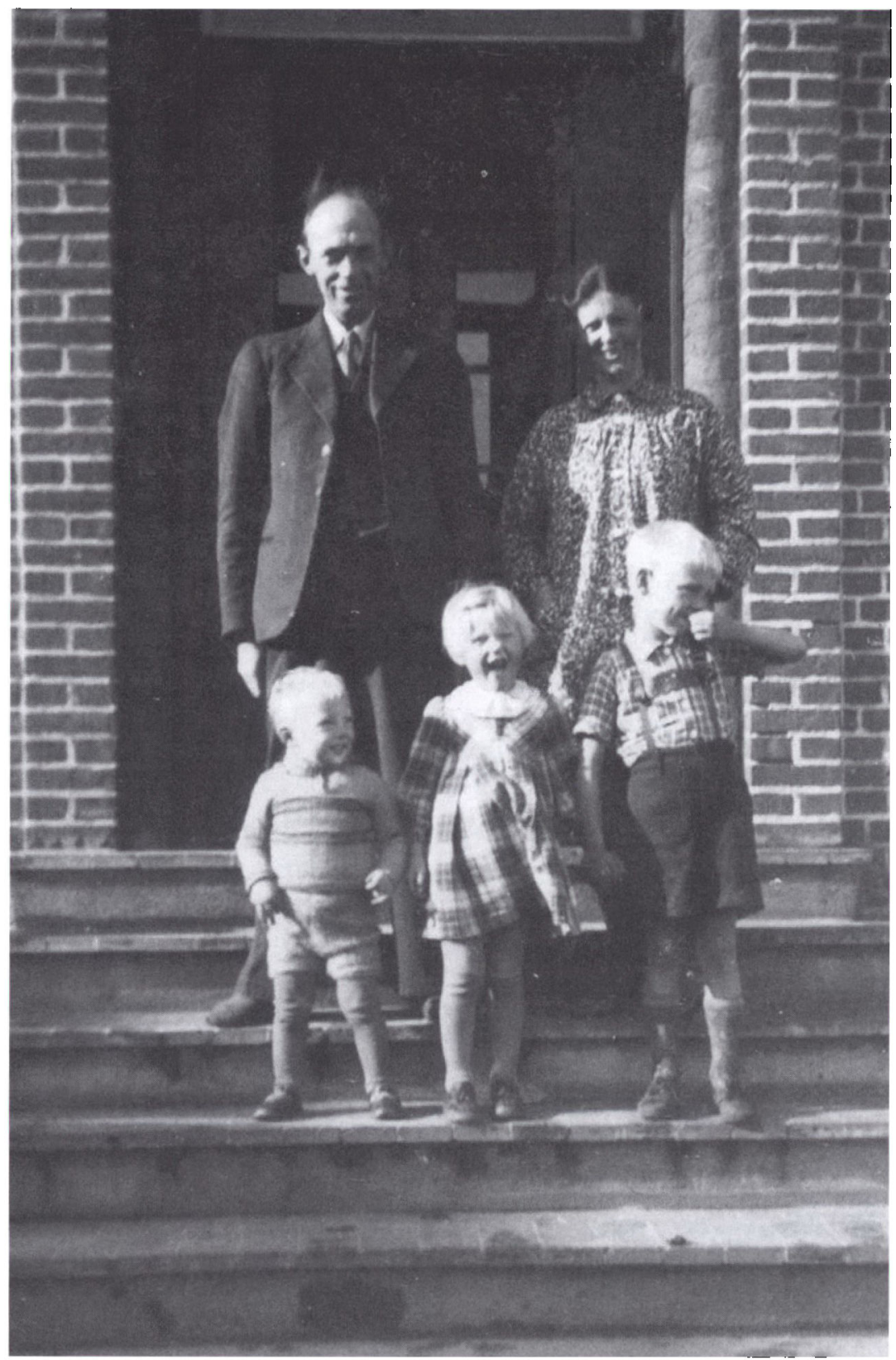

Familien Heick på trappen. Børnene er (set fra højre) Thorbjørn, Lisbet og Johannes. 1942. Privat foto. 
rum, rum til gruekedel, vaskekælder, et midterrum bl.a. til hjemmeslagteren, når han parterede. Dette rum blev også brugt som spisestue og opholdsrum for en gruppe tyske soldater, vi havde indkvarteret en overgang. Deres officer havde indlogeret sig i et af gæsteværelserne på første sal, og når han skulle ned til sine folk i kælderen, måtte han igennem køkkenet. Han kunne også have gået ud ad fordøren og rundt om huset og ned ad trappen til kælderen, men det fandt han vist ikke ud af. Ikke engang da han måtte bede min mor sige til pigerne, at de ikke skulle hilse på ham, når han gik igennem køkkenet. For det havde min mor sagt, at de skulle for at drille officeren, som så for hver hilsen var nødt til at stå stram og hilse igen.

Nederst $\mathrm{i}$ kælderen, bagerst til gårdsiden uden vinduer, var der endnu et ganske stort rum til opbevaring af diverse. Det var ikke bygget til det, men det blev brugt som beskyttelsesrum, når luftbombardementer var for tæt ved. Det sidste kælderrum var vaskerummet med gruekedlen i et rum foran. Her blev der også kogt det yderste af slagtegrisen, og på en eller anden måde blev det til en slags sæbe. Så var det lettere at forstå, at man af kartofler kunne lave det fineste kartoffelmel, når det opslemmede lå tilbage og tørrede på et lærred eller et lagen.

Mellem Rens og Store Jyndevad var der ikke et træ, ja, mellem Rens og Kruså var der næppe et træ, i hvert fald ikke ét læhegn. Det var medvirkende til, at der hvert forår kunne flyttes adskillige bunker sand, når der var sandstorm. Vi kender selv til det her i Tønder endnu i begyndelsen af det 21. århundrede. Der er noget, der hedder påskeøsten. Og man er ikke ret stedkendt, hvis man vasker sine vinduer inden påske. Det kan være spildt arbejde. Og det var ikke mindst læhegn, forsøgsstationen skulle lære egnen at indse nytten af. Derfor blev der plantet læhegn i kilometervis omkring forsøgsstationens marker, ikke blot omkring hele området, men om hver mark for sig. Læhegnene blev plantet $i$ tre rækker, yderst en række tjørn og en seljerøn og derimellem en række poppel, der skulle støtte opvæksten, men som senere blev fjernet, så der var mere plads til at rense mellem træerne. Omkring 1946 var der videnskabelige forsøg med læhegn. Træskeletter med varierende størrelse og mellemrum mellem brædderne blev stillet op. Forsøget, som i øvrigt udløste en doktorgrad, viste blandt andet, at et hegn ikke må være helt tæt. For når blæsten kommer til et sådant, stiger den blot lodret op og slår så ned igen lige bag hegnet. Og desuden blev det nu dokumenteret, at læhegn holder på fugtigheden, og at der er en grad mere varme på jorden indenfor. 
Også omkring selve forsøgsstationen og dens have blev der plantet hegn. Mens der blev bygget, var der kun den bare mark, og mens træerne var små, kunne man let se over dem. Og da de blev lidt større, kunne man let se igennem dem efter løvfald.

I forsamlingshuset i Store Jyndevad foregik det hele. Et andelsselskab havde bygget huset sidst i 1920'erne. Da man i 1929 tog fat i Store Jyndevad, tegnedes 100 private andele à $50 \mathrm{kr}$., mens de nationale foreninger sørgede for restbeløbet. Andelshaverne var de danske i en vid omkreds: Rens, Sofiedal, Eggebæk og Broderup. Flere af disse landsbyer fik senere forsamlingshuse. Jyndevad forsamlingshus er tegnet af arkitekt Jep Fink, Aabenraa, og kostede 20.000 kr. Det blev indviet på kongens fødselsdag den 26. september 1929, og festtalen blev holdt af H.P. Hanssen.

Forsamlingshuset var vort andet hjem. Vi var med til alt, hvad der foregik. Skoleloven fra 1937 krævede en gymnastiksal, og den havde vi i forsamlingshuset lige over for skolen. Der var også frivillig gymnastik. I forsamlingshuset blev desuden årets dilettant fremvist. I Martin Refslund-Poulsens »Tidsbilleder « på sønderjysk optrådte jeg som et barn. "Det lille teater « kom også på besøg. På sportspladsen var der ringridning og ellers håndbold, træning og kampe sommeren igennem. En gang om året tabte forsøgsstationen, og derefter var der dans til hr. og fru Søgårds duo.

Man kunne leje sig ind i forsamlingshuset. Værten, Albert Hansen, der også var daglejer på forsøgsgården, boede i forsamlingshuset sammen med sin familie. Private familiefester kunne der holde der, men den største bruger var Dansk Forening for Store Jyndevad og omegn. Den stod for de årlige, næsten rituelle fester: afstemningsfest 10. februar og kongens fødselsdag 26. september. De børn, der var for små til at deltage, blev imens passet af vor tyske nabokone, Marianne. Juletræsfest for børnene fandt sted fjerde juledag, med dans i tre kæder omkring det store juletræ og efterfølgende uddeling af poser fyldt med frugt og slik. Julen varede ved til helligtrekonger, hvor "grænsepræsten« N.P. Nielsen kom.

\section{Besættelsestiden 1940-1945}

Til at anlægge haven med græsplæner, køkkenhave, frugthave, tennisbane og et stort læhegn, nærmest en lille skov mod vest og nord (indbygget en snoet »kærlighedssti ; man skulle ikke kunne se fra den ene 
ende til den anden, sagde min far), havde vi en havebrugskandidat, Else, datter af mine forældres venner og læremestre, Karsten Iversens, Askov Forsøgsstation. Da der var uro ved grænsen om morgenen den 9. april, ville Else gerne hjem til Askov, og min far kørte hende i vores Opel Olympia, og jeg, treethalvt år gammel, fik lov at køre med på bagsædet. Men da vi kom til Broderup og skulle dreje til venstre mod nord til toget i Tinglev, kunne vi ikke komme ud på vejen. Sydfra kom en endeløs kolonne af tyske militærkøretøjer. Og ovre på den anden siden af vejen stod lokale hjemmetyskere (må det have været) og hilste heilende de forbikørende. Det er det første, jeg huske fra den køretur. Min far var jo lokalkendt, så han smuttede alligevel ud $\mathrm{i}$ kanten af vejen mod nord. For 50 meter henne kunne han køre ind til en gård og fra den køre ud på den vej, vi var kommet fra. Det gik godt, og vi kørte hjemad igen. Jeg sad, eller lå på knæ på bagsædet og kiggede bagud. Da vi var kommet vel en kilometer ud, så jeg, at en tysk kampvogn drejede ud på den vej, vi kørte på, og pegede på os med sin kanon. Det syntes jeg var uhyggeligt. Det er det andet, jeg kan huske.

I februar 1943 blev familiens fjerde barn født. Han kom til at hedde Niels Jørgen. Jeg husker, at han blev født tidligt om morgenen, for vi første tre børn, der boede i børneværelset ved siden af forældrenes soveværelse, to i køjeseng og en seng til den mindste, blev vækket tidligt ved sekstiden og gennet over i gæsteværelset. Vi vidste ikke, hvad der var gang i, som man siger nu om dage. Men lidt senere kunne vi høre et lille barn græde. Og vi så forundrede på hinanden, for det havde vi ikke hørt noget om. Det talte man åbenbart ikke så meget om dengang.

Jeg begyndte i folkeskolens første klasse 1. april 1943, hvor det nye skoleår begyndte, eftersom det gamle skoleår sluttede her, så man efter konfirmationen i syvende klasse kunne forlade skolen. Forudsat at man på det tidspunkt var 14 år gammel, for nu skulle man jo ud i voksenlivet.

Den folkeskoleordning, der kom i grænselandet efter 1920, er blevet beskrevet som »Genforeningens bedste gave«. Det er jeg enig i. Og det kan jeg bedst fortælle om ved først at beskrive de smukke skolebygninger, der blev opført i Jyndevad efter 1920. De lignede dem i Rens og i Burkal. Hvordan det var i Lydersholm, husker jeg ikke helt. Jeg ved kun, at lærer Leick, hjemkommen fra krigen og stadig $\mathrm{i}$ uniform - for det var, hvad han havde - $\mathrm{i}$ begyndelsen gik på omgang på gårdene. Hvordan det var i Sofiedal i sydøst og Lund i nordvest, 


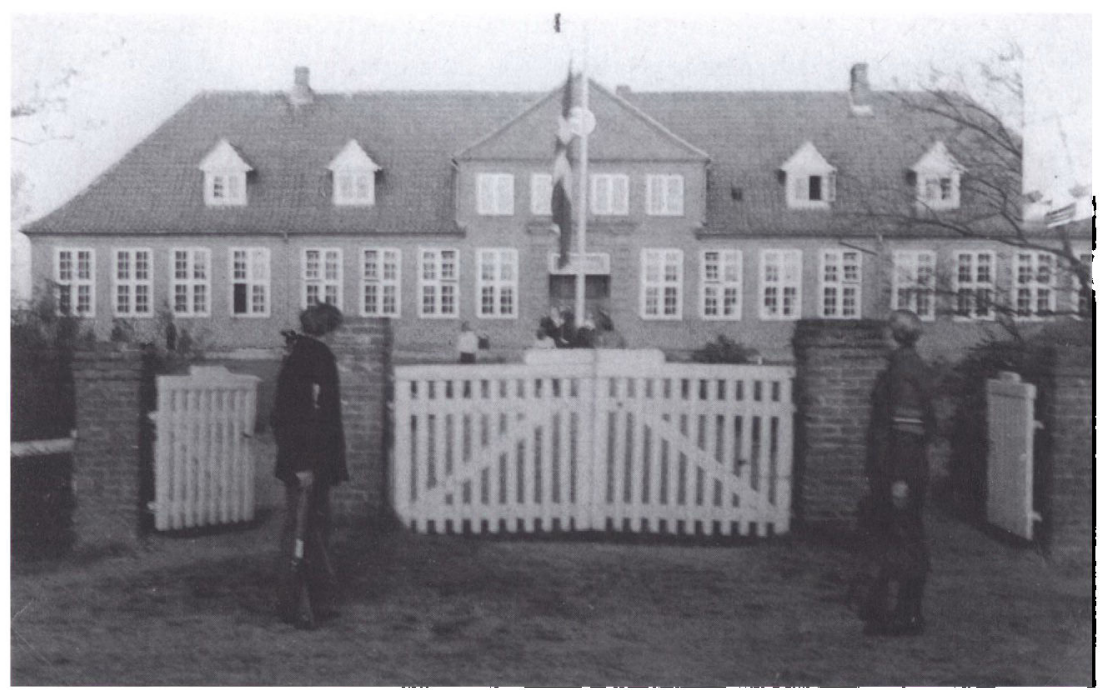

Store Iyndevad Skole. Dannebrog hejses under bevogtning af frihedskæmpere. Maj 1945. Privat foto.

ved jeg heller ikke, men nævner blot de andre skoler i mit sogn, hvor der alle steder kom betydningsfulde førstelærere: i Jyndevad lærer Spandet, i Rens lærer Hummeluhre og i Burkal lærer Dam. Og så ved jeg også, at Tønder Amts amtsskolekonsulent Nicolai Svendsen var en af de drivende kræfter i udformningen af folkeskolen i grænselandet efter Genforeningen.

Skolen i Store Jyndevad lå som en lang nord-syd længe midtfor, når man kom ind på pladsen, som havde en rund plæne med vej udenom. Lærerboligerne var bygget i samme stil. Til højre, mod nord, boede den danske førstelærer, til venstre den tyske lærer. I selve skolebygningen boede på første sal den danske andenlærer. Der var også en vej tværs gennem den runde plæne. Ad den kom man til skolens hoveddør. Når man gik ind, fandt man i den anden side den lange nord-syd gang. Gik man til højre, var der to klasserum med vinduer ud mod øst, ud mod skolepladsen. Det var de to danske klasserum, det ene for lille klasse (første til tredje årgang), det andet for store klasse (fjerde til syvende årgang). Børnene gik dog ikke lige ind $\mathbf{i}$ klasserummet. Der var en knagerække til overtøj og en hylde forneden til fodtøj. Det var mest om vinteren, man brugte sådant, træsko, træskostøvler, fedtlæderstøvler. Dem måtte man stille og tage "pus- 
ser« på (ofte med sål fra et gammelt cykeldæk), så man ikke ridsede det ferniserede gulv i skolestuen.

Skolen lå ca. 200 meter ned ad vejen mod Lille Jyndevad. Over for den lå forsamlingshuset. Syd for skolen byggede pedel Sogaard et hus, og nord for skolen blev der i tidens løb også bygget, så det blev til en hel lille bydel. Skolen i Jyndevad var et meget smukt byggeri i røde mursten. Stilen var den, der opstod i Danmark, efter at arkitektstuderende fra København omkring århundredskiftet (altså i tysk tid!) havde opmålt og aftegnet husene i Møgeltønder. Det blev vist kaldt »Bedre Dansk Byggeskik «. Arkitekter og murermestre fik kurser i det. I Rørkær fik gårdejer Brink omkring 1910 bygget sin gård i denne stil, tegnet af den senere professor Gottlob. Gården Tøndermark blev bygget i denne stil i 1933 og Jyndevad Forsøgsstation i 1939, begge tegnet af arkitekt Petersen, Tønder.

Om sommeren gik vi $\mathrm{i}$ bare ben. Man måtte gå $\mathrm{i}$ bare ben, når man havde hørt 'kukmanden' (gøgen); så var det sommer. Og sommeren varede til kartoffelferien, som efterårsferien med rette blev kaldt. For da var alle af hus, også kvinder og børn. Og det gav, syntes vi, en god skilling. Om sommeren gik vi i skole fra kl. 7 til 12. Det var et fremskridt fra den vestjyske ordning, hvor man om sommeren kun fik en eftermiddag om ugen. Mange skulle jo hjælpe derhjemme, men ellers var den udstrakte eftermiddag fri til leg. Jeg gik ikke i skole om sommeren, jeg løb den på hovedvej otte. For det var dejligt at komme i skole. Jeg løb mod den opgående sol. Måske var det løberytmen, der gjorde, at det sommetider, navnlig i forsommeren, var, som om solen dansede. Men hvis man forglemte sig under løbet, så kunne det ske, at storetåen ramte asfalten forkert. Det gjorde ondt, mens jeg humpede videre. Om vinteren gik vi, i hvert fald i store klasse, fra kl. 8.00 til 14.30, dog med en times middagspause, hvor byens børn, og jo navnlig læreren, kunne gå hjem til middagsmad. Vi andre havde vel madpakke med.

Gik man til venstre ad skolegangen, kom man til den tyske klasse. Der var kun beregnet et klasserum til børnene fra tysksindede hjem. Men de havde jo også kun én lærer. I hvert fald var det en udmærket ordning, når der nu skulle bygges nye skoler i grænselandet. Hvilket der var god grund til. Danske og tyske børn havde altså fælles skolevej og (så vidt jeg husker) fælles frikvarter. På skolevejen kunne det ske en gang imellem, at vi kom op at slås. Fjendskabet stak ikke dybt, hvis der overhovedet var noget. Men forskellen kunne selvfølgelig udnyttes, hvis slås-lysten kom. 
Der var lærermangel i 1940'erne. Andenlæreren var som regel ansat på vikarbasis. Så ud over førstelærer Spandet havde vi i disse år et utal af lærere, hvilket gør det svært at huske dem fra hinanden. For nogle år siden kom der ved en begravelseskaffe en mand hen til mig. Men jeg kunne ikke huske denne lærer Petersen. Heller ikke at han forsvandt ret pludseligt. Så det fortalte han så mig: En dag var Gestapo kommet for at hente ham. Men da de drejede ind på skolepladsen, tog de vejen til venstre og kom til den tyske lærers hus, hvor de spurgte efter Hr. Petersen. Den tyske lærer sagde, at Hr. Petersen desværre ikke var hjemme, så de måtte komme igen senere. Så tøffede Gestapo af, mens den tyske lærer gik over til sin danske Petersenkollega og sagde, at det nok var en god ide, hvis han rejste lidt væk. Hvilket han så straks gjorde. Alle vi seks søskende fik efter tur lejlighed til at gå i Jyndevad skole, inden de to yngste (Christian født 1947 og Dorete født 1952) i 1959 flyttede med forældrene til Viborg, hvor de boede i Overlund. Og så begyndte også på skoleområdet den nye tid i grænselandet. Dels kom der en lov om centralskoler, dels var der ikke så mange skolesøgende som tidligere. Det førte bl.a. til, at den smukke skole i Jyndevad blev nedlagt, og der kom noget skiftende småindustri i bygningerne.

Folketingsvalget i 1939 var meget vigtigt. Jeg husker ikke noget om det, men hørte i min opvækst gang på gang om, hvor vigtigt det var, at hjemmetyskerne ikke fik fremgang ved valget, for det kunne give dem og Adolf Hitler begrundelse for at kræve en grænseændring. Derfor måtte alle danske stemmer af hus. Og der kom i hvert fald nok til, at hjemmetyskerne ikke fik mere end det ene mandat, de $\mathrm{i}$ forvejen havde i Folketinget. Noget lignende var tilfældet ved det folketingsvalg, der så kom i 1943. Jeg husker, at vi snakkede om, at vor tyske genbo, Jürgen, havde en flagstang liggende parat, ja, et lager af dem. Tyskerne brugte ellers ikke flagstang. I 1943 gik vor genbo dog ikke så langt som til at anskaffe sig en "rigtig «, malet flagstang. Han og vel sagtens alle andre nøjedes med at afbarke et grantræ af passende størrelse. Men heller ikke denne gang fik tyskerne fremgang i Folketinget. De stillede ikke engang op, men fik et tysk kontor på Christiansborg, har jeg senere fundet ud af. Men Jürgen troede som så mange andre på deres sag, så han meldte sig ind i det tyske hjemmeværn, "Heimwehr«. Han bar altså tysk uniform. Den kom kun i brug til øvelser. Men det var nok til, at han og mange andre blev dømt for landsforræderi og måtte tilbringe et par år i Fårhus-lejren. 


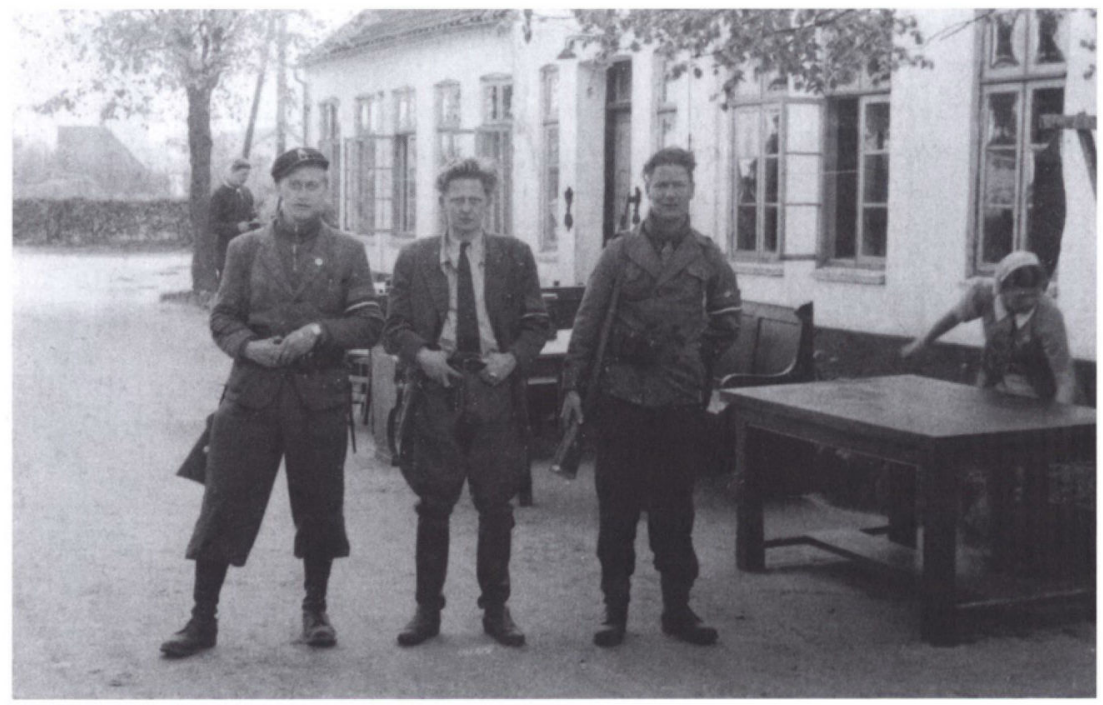

De tyske besættelsestropper var indkvarteret på Jyndevadhus, som de forlod den 7. maj 1945. Fra 8. juli til 29. oktober var et kompagni fra Den kongelige Livgarde, der $i$ den periode fungerede som grænsevagt, indkvarteret på Jyndevadhus. Inden livgarden rykkede ind, skulle der skures og skrubbes og renses ud efter tyskerne. Her ses nogle frihedskampere fotograferet foran Jyndevadhus, mens lederen af Jyndevadhus, Solvejg Refslund, til høje er $i$ gang med at gore et bord rent. Maj 1945. Privat foto.

En morgen i efteråret 1944 skete der noget uhyggeligt. Gestapo kom og tog vor gamle nabo, Josef, og nogle af vore tidligere karle med sig. Jeg mindes ikke, at der var nogen af de karle, der lige da var i tjeneste hos os, der blev taget den dag. Jeg ville have husket, hvis Gestapo var kommet ind på vores gårdsplads. Mens jeg var præst $\mathrm{i}$ Tønder, besøgte jeg den gamle hugaf, fhv. amtsforvalter Møller, der boede i det gamle amtshus ved Lille Torv. Han var meget døv og talte meget højt og havde altid en flaske rom til en grog stående. Og så kunne han fortælle om sin tid i modstandsbevægelsen. Han fortalte om den afholdte gymnastiklærer på Statsskolen, Rosenkjær, der også var leder $\mathrm{i}$ amtets karlegymnastik og derfor kunne samle mange unge om sig og få dem med. De holdt møder ude på Hestholm, hvortil der kun går en vej ned fra vejen ind til Tønder. En vagt kunne så i tide opdage, hvis der kom en bil. Møller var af og til sammen med skomager Bøgen i Bylderup-Bov ude for at sabotere jernbanen omkring Tinglev. De cyklede derover. Dengang cyklede man jo lange afstande for et godt ord. Engang havde han svært ved at komme ind i Tønder 


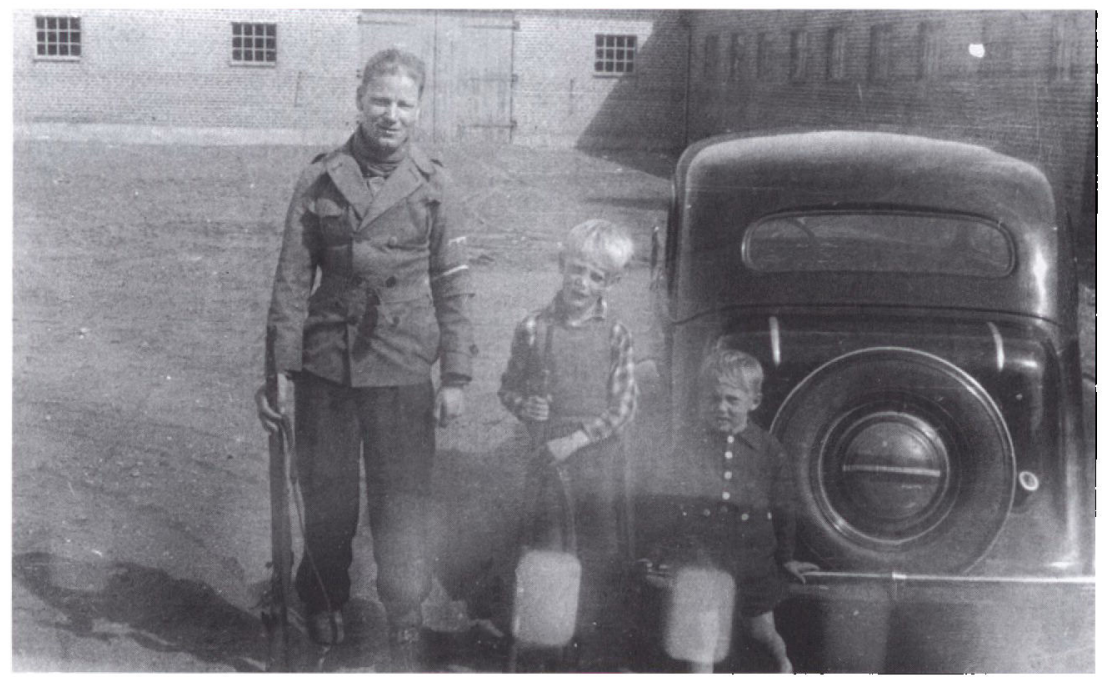

Thorbjorn og Johannes Heick sammen med en vagt fra modstandsbevægelsen $i$ gården til forsegsstationen. Maj 1945. Privat foto.

igen, da der var undtagelsestilstand. En anden gang havde han og Bøgen ikke lykkedes med en sabotage. Så cyklede de hjem over Jyndevad, gik ind til en af karlene i 'kavalerfløjen' og bad ham gemme sprængstoffet under sin seng. - Som jeg husker det: Den dag Gestapo kom, var de ikke ude efter nogen på forsegsstationen. Men de tog vor 60 år gamle nabo, Josef, og vore to 'gamle' karle, Mads og Lorens.

Lorens var fodermester nede i Stade, den lille samling huse, hvortil der går en vej mod nord lige ved forsøgsstationen mellem Jürgens ejendom og Josefs hus og sandgrav. Husene i Stade lå lige på den anden side af Sønderåen. Den største ejendom, Jeppe Jensens, lå længst borte mod vest. Her tjente Lorens Hansen det år. Lorens var ude i stalden, da Gestapo kom. Men han sagde, at han skulle da lige vaskes lidt og have noget andet tøj på. Men straks han kom ud i vaskerummet, stak han af ned mod åen, som han forsøgte at skjule sig i. Men det gik ikke. Så over til den anden side og i løb over markerne mod syd ned mod Pebersmark, hvor hans mor boede.

Da Gestapofolkene ikke kunne komme over åen, skyndte de sig til deres biler og rasede hen gennem Stade, over broen, op til hovedvej otte, mod vest til det sted, som Lorens havde krydset, og hvor han nu i spring over hegnene var på vej mod syd. Vi kunne følge det fra 
vinduerne i gæsteværelset på 1. sal. Gestapofolkene løb så godt, de kunne. Men når de kom til et hegn, måtte de skrå forsigtigt over for ikke at rive deres bukser på pigtråden. Alligevel fik de fat på Lorens.

Vor nabo, Josef, hed Janecki til efternavn. Han var fra et sted i Polen. Han var stenstryger, det vil sige han lavede cementsten m.v. fra den lille sandgrav langs vejen ned til Stade. Han var det elskeligste menneske. Det samme var hans kone, Martha, som var fra Esbjerg. De havde ingen børn. Josef var vel kommet herop som følge af 1. Verdenskrigs virvar. Hvorfra i Polen han kom, ved jeg ikke. Men da jeg efter hans død strejfede rundt $i$ hans blikskurs stenstrygeri, fandt jeg et sted under taget en seksløber revolver, ni millimeter. I læderetuiet stod et østpolsk bynavn. Den revolver var mit kæreste eje de næste ti år. Josef har sikkert ikke været med til sabotage, men han var god at gemme sprængstof hos, indtil gruppen altså blev rullet op, og han selv kom i pinligt forhør på Staldgården i Kolding. Han måtte tilstå at have sprængstof mv. gemt. Det havde han gravet ned under gulvet i et lille beskyttelsesrum, han havde lavet bag sit hus. Gestapo kom med ham, og han viste dem, hvor sagerne lå.

Så blev Mads og Lorens og Josef indsat i Frøslev. Lejren var jo ikke sådan at komme ind i for uvedkommende. Men vor genbos nabo mod vest på Vesterholm, Christian Völkers, leverede kål til lejren. Og så magede vores markassistent, Niels Schultz, det sådan, at det blev ham, der var kusk på den hestevogn, der kørte med kål til lejren i Frøslev. På den måde fik vi nyt om, hvordan de tre og andre bekendte havde det. Senere blev de alle tre sendt til Neuengamme. Jeg har senere besøgt det sted lige øst for Hamborg.

Man må sige, at Josef kom til at arbejde med sten her. Tipvognen skulle skubbes med hænder, også op ad den stejle, vel 70 meter lange slisk. Ikke nok med det. Josef fik sine støvler stjålet, så han måtte vandre barfodet. Han fik lungebetændelse og døde på sengehylden, hvor han lå mellem Mads og Lorens. Men han kunne gøre dem en sidste tjeneste. For om morgenen kom vagterne og talte ud fra de oprejste arme, hvor mange der var til et stykke morgenbrød. Og så kunne de den morgen også løfte den døde Josefs arm.

I april 1945 lykkedes det for det danske departementchefstyre gennem svenske Folke Bernadotte at få lov til at sende de (hurtigt malede) hvide busser til Neuengamme for at hente danske og norske til Sverige. Det var ikke tilladt at stå af $\mathrm{i}$ Kruså, hvor de hvide busser fik en hjertelig velkomst. De fleste var nok også for svage til det. Men 
nogle smuttede af undervejs. Her vil jeg afslutte dette afsnit med at fortælle, hvor magre og trætte Lorens og især Mads var, da de kom hjem, og vi så dem på forsøgsstationen. De blev begge agronomer. Lorens Hansen blev forstander for landbrugsskolen ved Velling, Mads Madsen blev landbrugskonsulent i Sydslesvig.

En af dem, der kom med de hvide busser fra Neuengamme og smuttede af i Kruså, var Poul Andersen. Han ville hjem til sin kone og sit landbrug ved Højer og syntes, at han var rask nok til det. Han var i hvert fald rask nok til at spadsere de 20 kilometer ud til forsøgsstationen. Men han måtte jo være under jorden, indtil freden kom. $\mathrm{Nu}$ traf det sig sådan, at man på forsøgsstationen var ved at forberede forsøg med kunstig vanding, noget som de følgende år gjorde Jyndevad Forsøgsstation om ikke landskendt, så dog kendt og besøgt og efterlignet af mange landbrug på den jyske sandjord. Poul Andersen kom lige betids til, at han uden at vække opsigt kunne blive ansat som tilkaldt ekspert til dette projekt. Han måtte selvfølgelig have et andet navn og dertil hørende falske papirer. Så han lød navnet Anders Poulsen og var med til at bygge et lille pumpehus fra den bæk, der løb ud af Josefs sandgrav og ned i Sønderåen. Mine forældre og Poul Andersens havde ikke omgåedes privat, så fru Andersen blev noget forbavset, da min far ringede til hende og inviterede hende til eftermiddagskaffe. Mere kunne han ikke sige i telefonen. Men hun kom dog. Efter krigen gik det op for Poul Andersen, at han hellere ville lave noget andet end være landmand. Så han blev kørelærer i Tønder, også min kørelærer, så jeg kunne få kørekort, da jeg blev 18 i november 1954. Og jeg fik det virkelig. Min far havde sagt, at hvis jeg ikke røg, før jeg blev 18, så ville han give mig kørekortet.

Min far fortæller i sin levnedsbeskrivelse, at forsøgsstationen var med i de planer, som modstandsbevægelsen/Frihedsrådet havde lagt om, hvad der skulle gøres, når/hvis Tyskland kapitulerede. Grænsen skulle kontrolleres, hverken personer eller ting skulle kunne slippe ud af landet uden tilladelse. Og her lå Jyndevad Forsøgsstation meget praktisk ved hovedvej otte, midt mellem Kruså og Tønder, med 20 kilometer til hvert sted. Vandrerhjemmet i Store Jyndevad kunne ikke bruges. Der lå der en tysk styrke. Men efterskolen i Rens kunne bruges. Og begge steder forberedte sig til dansk indkvartering.

Alt dette vidste jeg, en knægt på otte år, selvfølgelig ikke noget om. Men vi hørte jo som sædvanligt BBC's danske radio også den aften, som gjorde et mere uudsletteligt indtryk på danske, jo ældre de var. 


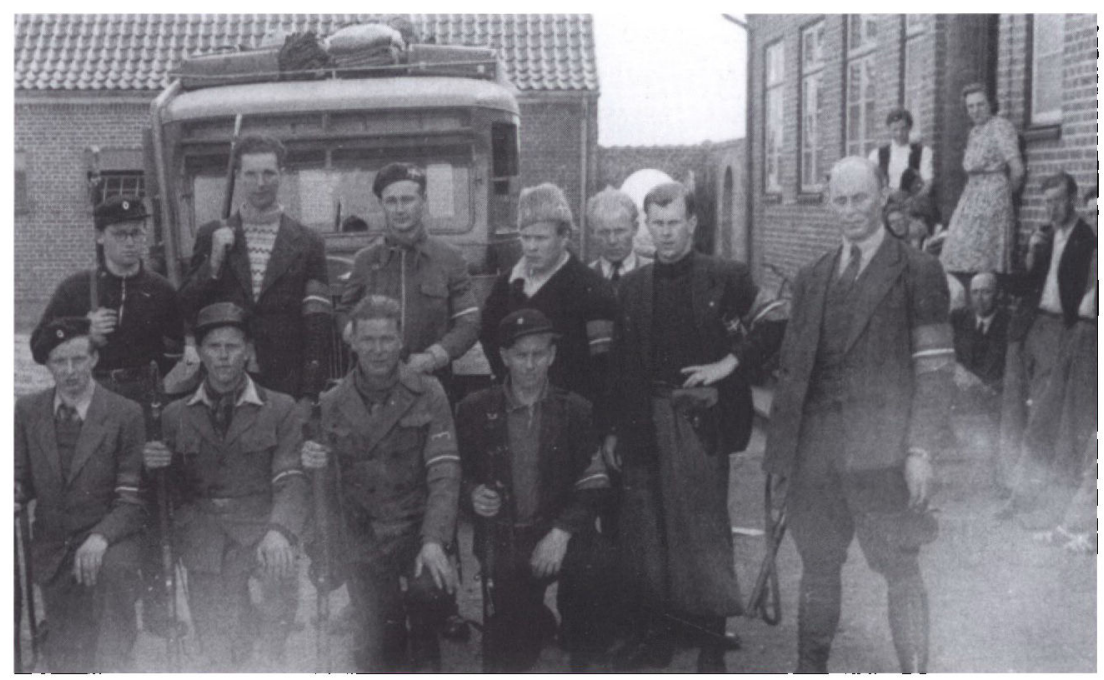

En gruppe frihedskæmpere $i$ gården til Jyndevad Forsagsstation. Forstander Frederik Heick sidder på trappetrinnet. Maj 1945. Privat foto.

Jeg forstod blot, at noget afgørende var sket, at det i dette øjeblik, midt $\mathrm{i}$ udsendelsen, kunne meddeles fra Montgomery på Lyneborg hede, at de tyske tropper i Holland, Nordvesttyskland og Danmark havde kapituleret betingelsesløst. Det skete sidst på dagen fredag den 4. maj 1945. I lejren i Frøslev førte det i løbet af lørdagen til, at rollerne skiftede. Nu var det de danske indsatte, der overtog kontrollen, og de tidligere vogtere var nu bevogtet bag hegnet. Og søndag den 6 . maj ved aftenstid kom der to busser fyldt med tidligere indsatte fra Frøslevlejren.

I min erindring kom de allerede dagen efter den 4. maj, men det var også i min erindring søndag, da de kom. Flaget var hejst, og det var, som om forsøgsstationens gårdsplads var bygget til formålet, da frihedskæmperne stillede op med ryggen til de tre fløje og ansigtet mod flaget og mod den, der nu talte til dem. Min far fortæller, at de var dårligt bevæbnede. Men jeg erindrer det sådan, at de alle var bevæbnede, mindst en revolver havde hver mand med sig fra Frøslev, på nær to.

Jeg husker også, at min far derefter førte en gruppe af dem ned over forsøgsstationens marker, ned til Lille Jyndevad, hen forbi købmand Mortensen og ned til grænsen ved Bøgelhus. Jeg spekulerede ikke på, hvordan grænseovergangen ved Pebersmark mon blev kon- 
trolleret, men det må jo være sket fra Rens Efterskole. Og selv om min mor åbenbart havde forberedt sig med beholdninger på lager, så blev jeg mandag formiddag sendt til slagteren i Rens efter nogle kødvarer. Og jeg kendte jo vejen. Den havde jeg cyklet i modsat retning seks år tidligere, dengang på en trehjulet. Nu havde jeg en rigtig cykel. I stedet for dæk havde jeg ganske vist to stykker fra en haveslange. Men det fungerede udmærket i flere år.

Det må altså have været mandag den 7. maj, at jeg var på vej de tre kilometer til Rens. Men jeg var ikke kommet længere end en kilometer, før der lå en riffel $\mathrm{i}$ grøften. $\mathrm{Og}$ ihukommende de to frihedskæmpere, der manglede våben, vendte jeg straks om med riflen over skulderen. Der manglede godt nok lås på den, men jeg fik den afleveret og begav mig så på vej til Rens igen. Men et par hundrede meter efter den første lå der nu igen en riffel fra en træt tysk soldat. Så nu kunne den anden, der manglede, også få en. Og jeg af sted hjemad igen. Men da jeg var næsten hjemme, måtte jeg stå stille i vejkanten, for der kom en bilkolonne med tyske soldater. Og jeg stod så der i vejkanten med min cykel og min riffel. De fleste soldater vinkede til mig, men der var en løjtnant, som så meget bistert på mig, og jeg tænkte: Nu skyder han mig! Men der skete ikke noget, og jeg kunne så aflevere min riffel nummer to, og så lykkedes det mig at komme til slagter Langholz og hjem igen uden nye militære byrder.

Jeg erindrer ellers ikke noget fra sommeren 1945, ikke andet end at en af frihedskæmperne, Orla hed han, kom til at skyde sig selv i foden, da han fumlede med sin maskinpistol, da der kom nogen. Det er jo en slags billedtale "at skyde sig selv i foden «, når man i stedet for andre rammer sig selv, men her skete det virkelig bortset fra, at Orla ikke havde villet skyde nogen, blot være parat. De havde jo heller ikke megen militær træning bag sig, de fleste af de første grænsevagter. Desuden har de jo sikkert gerne villet tilbage, hjem til deres dagligdag, efter opholdet i Frøslev. Og der kom heldigvis ret snart afløsning. Nemlig af den danske brigade, som var blevet dannet og uddannet i Sverige, og som straks var kommet over Sundet den 5. maj. Men det tog jo nogle dage, før dens folk også kunne tage sig af grænsen.

Jeg ved ikke, hvor børnene fra den tyske afdeling af folkeskolen i Jyndevad gik i den første tid efter befrielsen. De har ikke haft tysk lærer. Så måske vi har gået sammen. Men hen i 1946 har de blå gendarmer vel overtaget grænsebevogtningen igen. Og dermed kunne 


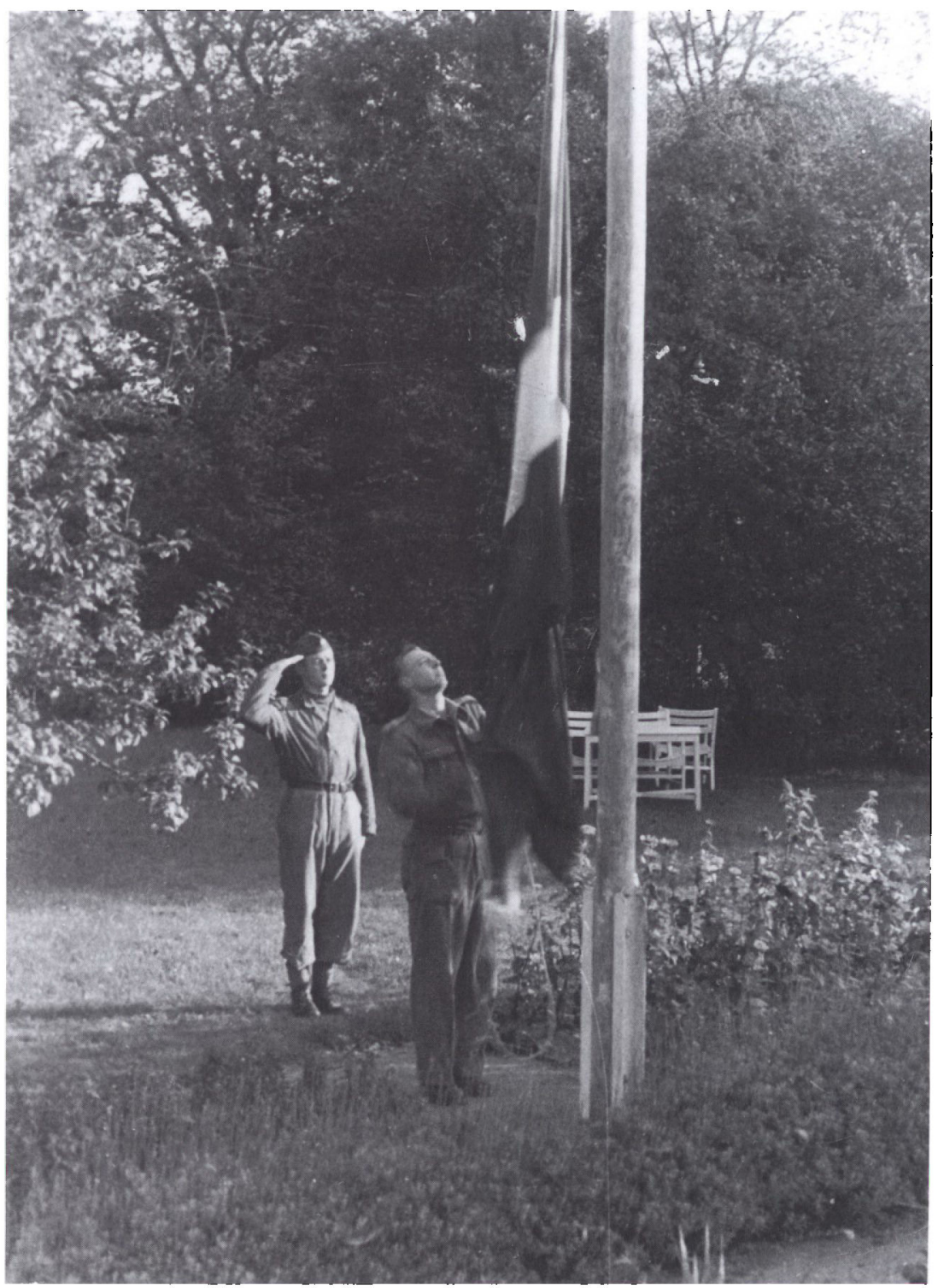

Hver morgen hejste livgarden Dannebrog fra Jyndezadhus' flagstang. Juli 1945. Privat foto.

hjemmetyskerne i Jyndevad genovertage deres forsamlingshus (det var blevet beslaglagt af de gardersoldater, der kom efter brigadesol- 
daterne). Det passede vel med, at de første af mændene begyndte at komme hjem fra Fårhuslejren. Og det passede også med, at hjemmetyskerne nu dannede friskoler. Så fra nu af og i adskillige år gik de tyske børn til skole der. Og de tyske unge drev sport der. Og i det hele taget havde tyskerne deres forsamlingshus der, ligesom vi havde vort forsamlingshus. I grænselandet havde vi som regel to af alting: to skoler, to forsamlingshuse, to ungdoms- og idrætsforeninger. Og ikke at forglemme: to ringridninger. Ringridningerne har hver deres farve. De danske rød-hvide, de tyske hvid-grønne. Det var også farverne på vimplerne, når et byggeri havde rejsegilde. Da der var rejsegilde på forsøgsstationen i 1939, havde mine forældre den glæde, at der var syv vimpler af hver slags. Byggeriet hilstes altså velkomment også af de hjemmetyske. Ellers kom vi ikke hos hinanden.

Det var først hen omkring 1960, at jeg selv fik ærinde i det tyske forsamlingshus. Jeg havde som student fảet et sommerferiejob med at indføre en blandet gruppe udenlandske unge i grænselandsforhold. Jeg fik dem indkvarteret på vandrerhjemmet i Jyndevad og måtte jo først planlægge og aftale besøg både $i$ institutioner for flertal og mindretal syd og nord for grænsen. Og da var jeg for første gang selv på besøg i det tyske forsamlingshus. 
